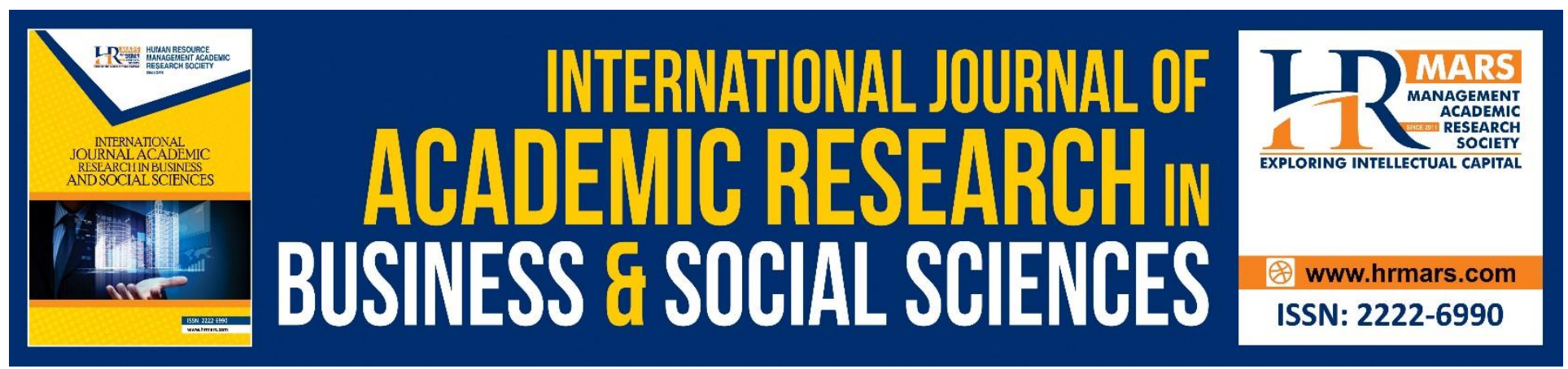

\title{
The Legitimacy of "Responsibility to Protect" (R2p) in International Relations: A Conceptual Review
}

\author{
Mohd Afandi Salleh \\ Usman Safiyanu Duguri
}

To Link this Article: http://dx.doi.org/10.6007/IJARBSS/v9-i3/5700

DOI: $\quad 10.6007 /$ IJARBSS/v9-i3/5700

Received: 25 Feb 2019, Revised: 19 March 2019, Accepted: 03 April 2019

Published Online: 09 April 2019

In-Text Citation: (Salleh \& Duguri, 2019)

To Cite this Article: Salleh, M. A., \& Duguri, U. S. (2019). The Legitimacy of "Responsibility to Protect" (R2p) in International Relations: A Conceptual Review. International Journal of Academic Research in Business and Social Sciences, 9(3), 401-410.

\section{Copyright: (C) 2019 The Author(s)}

Published by Human Resource Management Academic Research Society (www.hrmars.com)

This article is published under the Creative Commons Attribution (CC BY 4.0) license. Anyone may reproduce, distribute, translate and create derivative works of this article (for both commercial and non-commercial purposes), subject to full attribution to the original publication and authors. The full terms of this license may be seen at: http://creativecommons.org/licences/by/4.0/legalcode

Vol. 9, No. 3, 2019, Pg. 401 - 410

Full Terms \& Conditions of access and use can be found at http://hrmars.com/index.php/pages/detail/publication-ethics 


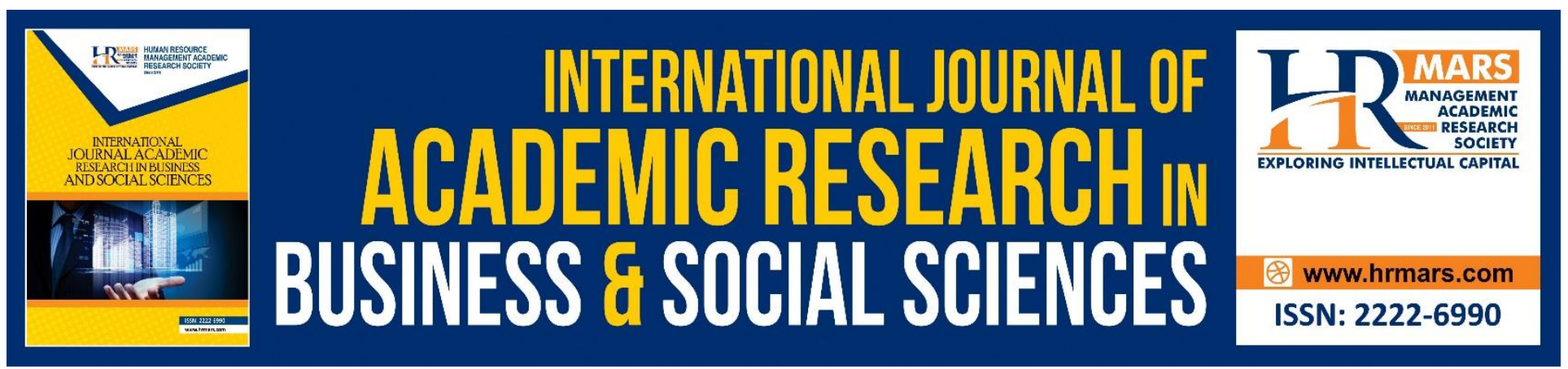

\title{
The Legitimacy of "Responsibility to Protect" (R2p) in International Relations: A Conceptual Review
}

\author{
Mohd Afandi Salleh \\ Faculty of Law and International Relations, Universiti Sultan Zainal Abidin, Gong Badak Campus, \\ 21300 Kuala Nerus, Terengganu, Malaysia \\ Usman Safiyanu Duguri \\ Faculty of Law and International Relations, Universiti Sultan Zainal Abidin, Gong Badak Campus, \\ 21300 Kuala Nerus, Terengganu, Malaysia
}

\begin{abstract}
Responsibility to Protect (R2P) is a new concept in international relations which can be defined as an intervention in a state by the international community (preferably through the UN) for the prevention of genocide, ethnic cleansing, mass killings and human rights violations taking place, in a country which is unwilling (or unable) to stop it. The obligation then falls on the wider international community to take whatever action is necessary to prevent it. The concept formed 20 years ago after it was floated in the 1980s, initiated by Gareth Evans and finally endorsed by Kofi Annan in the 1990s, before being adopted as a concept by the UN's World Leader's Summit in 2005. This paper systematically reviews and examines the legitimacy of the concept and its coexistence within the framework of international relations. The study reveals that the concept of Responsibility to Protect (R2P) is morally sound and accepted by the international community, but difficult to implement. R2P concept is a challenge for public society and the broader peace movement. It is suggested that for countries that are caught in a vicious circle chaos and anarchy, there is a need to implement the R2P to overcome their problems and save the civilian population.
\end{abstract}

\section{INTRODUCTION}

The concept and practice of The Responsibility to Protect (R2P) was born out of the international community's failure to respond to tragedies such as the Rwandan genocide in 1994 and the massacre in Srebrenica in 1995. Furthermore, it was Kofi Annan, Assistant Secretary-General at the UN Department for Peacekeeping Operations during the Rwandan genocide, who realized the international community's failure to respond. In 2000, Kofi Annan in his capacity as UN SecretaryGeneral wrote the report 'We the Peoples' The role of the United Nations in the 21st Century, in which posed the following questions: "if humanitarian intervention is, indeed, an unacceptable 
assault on sovereignty, how should we respond to a Rwanda, to a Srebrenica - to gross and systematic violations of human rights that offend every precept of our common humanity? (International Development Research Centre, 2001).

The issue of African roots that happened in year 2000 is considered as a gate for our discussion. Previously claimed by many critics of the R2P's third pillar that Responsibility to protect' is a Western concept. However, it was later understood that, the African Union (AU) that had in 2000 first pioneered the concept that the international community has a responsibility to intervene in crisis situations if a state is failing to guard its populace from mass atrocity crimes. Consequently, the AU has the right to intervene in a member state as enshrined in Article 4(h) of its Constitutive Act, which states "the right of the Union to intervene in a Member State pursuant to a decision of the Assembly in respect of grave circumstances, namely war crimes, genocide and crimes against humanity" The AU also adopted the Ezulwini Consensus in 2005, which welcomed R2P as a tool for the prevention of mass atrocities. Without any gainsaying, or being exaggerated, the origin of this program can be traced back to Africa (Soderlund, 2013).

According to the International Commission on Intervention and State Sovereignty (ICISS, 2001) In February 2001, at the third round table meeting of the ICISS in London, Gareth Evans, Mohamed Sahnoun and Michael Ignatieff suggested the phrase "responsibility to protect" as a way to avoid the "right to intervene" or "obligation to intervene" doctrines and yet keep a degree of duty to act to resolve humanitarian crises. Moreover, in 2001, ICISS released a report titled 'The Responsibility to Protect'. In a radical reformulation of the meaning of state sovereignty, the report argued that sovereignty not only entailed rights, but also responsibilities, specifically a state's responsibility to protect its people from major violations of human rights. This idea rested on earlier work by Francis Deng and Roberta Cohen regarding Internally Displaced Persons. The ICISS report further asserted that where a state was "unable or unwilling" to protect its people, the responsibility should shift to the international community and "the principle of non-intervention yields to the international responsibility to protect." The ICISS argued that any form of military intervention should be guided by the following six criteria to be justified as an extraordinary measure of intervention:

1. Just cause - Is the threat a "serious and irreparable harm occurring to human beings"?

2. Right intention - Is the main intention of the military action to prevent human suffering or are there other motives?

3. Final resort - Has every other measure besides military invention been taken into account? (This does not mean that every measurement has to be applied and failed, but that there are reasonable grounds to believe that only military action would work in that situation)

4. Legitimate authority

5. Proportional means - Are the minimum necessary military means applied to secure human protection?

6. Reasonable prospect - Is it likely that military action will protect human life, and are the consequences of this action sure not to be worse than no action at all?

As the ICISS report was released in 2001, right around the time of the Second Gulf War, many thought that would be the end of this new norm. However, in 2005, at the World Summit, where the largest number of heads of state and government in the history of the UN convened, the Responsibility to Protect was unanimously adopted. While the outcome was close to the ideas of the ICISS report, 
there were some notable differences: the R2P would now only apply to mass atrocity crimes (genocide, war crimes, crimes against humanity and ethnic cleansing), rather than human rights violations, the UN Security Council was recognized with being the only body allowed to authorize intervention. The paragraphs also stress the importance of regional organizations and the role they can play through Chapter VIII of the UN Charter. (Bellamy, 2008)

\section{RESPONSIBILITY TO PROTECT DOCTRINE}

Responsibility to Protect is a concept for intervention in a state by the international community (which preferably through the UN) for the prevention of genocide, ethnic cleansing, mass killings and human rights violations taking place, in a country which is unwilling (or unable) to stop it. At that time, the wider international community then has a collective responsibility to take whatever action is necessary to prevent it.

It is central to human security in all its dimensions. It is crucial to building post-conflict societies, supporting the rule of law, multilateral and democratic institutions. R2P is an intellectual breakthrough, a shift in politics, where more and more public opinion and governments are coming around the idea to the fact that something needs to be done to avoid genocide or mass killing if it is taking place in a country. The concept took 20 odd years to be formed after it was floated in the 1980s, initiated by Gareth Evans and endorsed by Kofi Annan in the 1990s, before being adopted as a concept by the UN's World Leader's Summit in 2005. In addition, the summit endorsed the socalled "Responsibility to Protect", subsequently approved by the Security Council, establishing the principle that sovereignty of a country is not sacrosanct and that the Security Council should be prepared to act when countries either commit or fail to prevent genocide or crimes against humanity on their territories. It is a moral rather than a legal obligation. We will today explore how the international community can take actions to enforce it via the route of international Criminal Court, the UN Security Council, and citizen initiatives. Responsibility to Protect is a recently developed concept in international relations. It aims to provide a legal and ethical basis for "humanitarian intervention": the intervention by external actors (preferably the international community through the UN) in a state that is unwilling or unable to fight genocide, massive killings and other massive human rights violations. (Stockburger, 2010)

The concept places a moral pressure on states to protect the human rights of people in countries other than their own. If a particular state is unwilling or unable to carry out its responsibility to prevent such abuses, that responsibility must be transferred to the international community, which will solve problems primarily via peaceful means (such as diplomatic pressure, dialogue, even sanctions), an expression of universal morality or, as a last resort, through the use of military force. Some criticize the responsibility to protect as a form of "Western imperialism". Other says that it places too much emphasis on violence and does not address equally devastating cases of famine and poverty. Many also question the focus on military interventions, which can encourage governments to take unilateral military actions for their own agenda. (Stockburger, 2010) 
INTERNATIONAL JOURNAL OF ACADEMIC RESEARCH IN BUSINESS AND SOCIAL SCIENCES

Vol. 9, No. 3, March, 2019, E-ISSN: 222 2-6990 ¿ 2019 HRMARS

\section{THE THREE FUNDAMENTAL PILLARS OF R2P}

Another work states that the Responsibility to Protect is an emerging norm that sovereignty is not a right, but that states must protect their populations from mass atrocity crimes - namely genocide, crimes against humanity, war crimes and ethnic cleansing. The R2P has three foundation "pillars"(Bellamy, 2015):

1. It is the responsibility of a state to protect its population from genocide, war crimes, crimes against humanity, and ethnic cleansing.

2. Also the international community has a responsibility to assist the state to fulfil its primary responsibility. If the state manifestly fails to protect its citizens from the four above mass atrocities and peaceful measures have failed, the international community has the responsibility to intervene through coercive measures such as economic sanctions. Military intervention is considered the last resort.

3. The Third pillar is the "responsibility to rebuild".

While R2P is a norm and not a law, it is firmly grounded in international law, especially the laws relating to sovereignty, peace and security, human rights and armed conflict. Responsibility to protect provides a framework for using tools that already exist, i.e. mediation, early warning mechanisms, economic sanctioning, and chapter VII powers, to prevent mass atrocities. Civil society organizations, states, regional organizations, and international institutions all have a role to play in the R2P process. The authority to employ the last resort and intervene militarily rests solely with United Nations Security Council. Criticisms of the R2P include a "moral outrage and hysteria that often serve as a pretext for 'interventions by the civilized world' or 'the international community' and for 'humanitarian interventions', which often conceal the true strategic motives, and it thus becomes another name for proxy wars. The clarification about the difference between responsibility to protect and humanitarian intervention is made vividly in the following topic.

4. The Difference between "Responsibility to Protect" and "Humanitarian Intervention" The Responsibility to Protect differs from humanitarian intervention in four important ways: First, humanitarian intervention is only military intervention. R2P, on the other hand, is first and foremost a preventative measure, that stresses state responsibilities. Military intervention may only be carried out as a last resort, when all other, non-coercive measures have failed and when the Security Council authorizes it. R2P is to extend the intervention beyond a purely military intervention and to encompass a whole continuum of obligations:

The responsibility to prevent: addressing root causes of internal conflict. The ICISS considered this to be the most important obligation.

The responsibility to react: responding to situations of compelling human need with appropriate measures that could include sanctions, prosecutions or military intervention. 
The responsibility to rebuild: providing full assistance with recovery, reconstruction and reconciliation.

The second point is related to the first and: R2P is firmly rooted in international law, especially the law relating to sovereignty, peace and security, human rights and armed conflict Humanitarian intervention, on the other hand, regularly violated Article 2.4 of the UN Charter, which outlines the territorial integrity of every sovereign state. R2P avoids this through the fact that a military intervention must either be authorized by the state in question or by the UN Security Council (Chapter VII of the UN Charter gives the Security Council the authority to do this).

Third, while humanitarian interventions have in the past been justified through the prevention of human rights abuses, the R2P focuses only on the four mass atrocity crimes: genocide, crimes against humanity, war crimes and ethnic cleansing. The first three crimes are clearly defined in international law and codified in the Rome Statute that established the International Criminal Court. Ethnic cleansing is not a crime defined under international law, but has been defined by the UN as "a purposeful policy designed by one ethnic or religious group to remove by violent and terror-inspiring means the civilian population of another ethnic or religious group from certain geographic areas.

Finally, while humanitarian intervention assumes a 'right to intervene', the R2P is based on a 'responsibility to protect' Humanitarian intervention and the Responsibility to Protect (R2P) both agrees on the fact that sovereignty is not absolute. However, the R2P doctrine shifts away from statecentered motivations to the interests of victims by focusing not on the right of states to intervene but on a responsibility to protect populations at risk. In addition, it introduces a new way of looking at the essence of sovereignty, moving away from issues of 'control' and emphasizing 'responsibility' to one's own citizens and the wider international community. (ICISS, 2001)

\section{PRINCIPLES FOR MILITARY INTERVENTION}

The just cause threshold.

Military intervention for human protection purpose is an exceptional and extraordinary measure. To be warranted, there must be serious and irreparable harm occurring to human beings, or imminently likely to occur, of the following kinds (Bellamy, and Williams, 2011)

a. Large scale loss of life, actual or apprehended, with genocidal intent or not which is the product either of deliberate state action or state neglect or inability to act, or a failed state situation, or

b. Large-scale ethnic cleansing actual or apprehended, whether carried out by killing forced explosion acts of terror or rape.

The precautionary principles

a. Right intention; the primary purpose of the intervention, whatever other motives intervening states may have, must be to halt or avert human suffering. Right intention is better assured with multi-lateral operation, clearly supported by regional opinion and the victims concerned.

b. Last resort; military intervention can only be justified when nonmilitary option for the prevention or peaceful resolution of the crisis has been explored with reasonable grounds for believing lesser measure would not have succeeded. 
c. Proportional means; the scale, duration and intensity of the planned military intervention should be the minimum necessary to secure the defined human protection objective.

d. Reasonable prospects; there must be a reasonable chance of success in halting or averting the suffering which has justified the intervention, with the consequences of action not likely to be worse than the consequences of inaction.

Right Authority

a. There is no better or more appropriate body than the United Nation Security Council (UNSC) to authorize military intervention for human protection purpose. The task is not to find alternatives to the Security Council (SC) as a source of authority, but to make the Security Council work better than it has.

b. Security Council Authorization (SCA) should in all cases be prior to any military intervention action being carried out. Those calling for an intervention should formally request such authorization, or have the council raise the matter on its own initiative, or have the Secretary-General raise it under Article 99 of the UN Charter.

c. The Security Council (SC) should deal promptly with any request for authority to intervene where there are allegations of large-scale loss of human life or ethnic cleansing. It should in this context seek adequate verification of facts or conditions on the ground that might support a military intervention.

d. The permanent fire members of the Security Council should agree not to apply their veto power in matters where there vital state interests are not involved, to obstruct the passage of resolutions authorizing military intervention for human protection purpose for which there is otherwise majority support.

e. The Security Council (SC) should take into account in all its deliberations that, if it fails to discharge its responsibility to protect in conscience-shocking situations crying out for action, concerned states may not rule out means to meet the gravity and urgency of that situation and that the stature and credibility of the United Nations (UN) may suffer thereby.

\section{Operation Principles}

a. Clear objectives, clear and unambiguous mandate at all time and resources to match.

b. Common military approach among involved partners, unity of command, clear and unequivocal communication, and the chain of command.

c. Acceptance of limitations, and gradualism in the application of force, the objective being protection of a population, not defeat of a state.

d. Rules of engagement, which fit the operation concept, are precise, reflect the principle of proportionality, and involve total adherence to international humanitarian law (IHL).

e. Acceptance that forces protection cannot become the principal objective.

f. Maximum possible coordination with humanitarian organization ( $\mathrm{HO})$.

The Responsibility to Protect and the Problem of Regime Change 2011 witnessed several responses from masses requested for change. The most common is the life historical Arab uprising that led to huge changes throughout Arab countries like Algeria, Egypt, Iraq, Libya, as well as Syria where thousands of people are dying every day and some non-Arab African countries like Cote d'Ivoire. Syria 
is the most affected country regarding the lack of responsibility to protect. Today, Nigeria has become a country of haramazation of book (book haram). This violence leads to shedding of bloods without any government intervention. The recent issue proclaims it and shows that there is a need of United Nation Intervention (UNI) to bring end to these political hurdles and to respect human rights.

According to Alex J. Bellamy (September, 2011), the use of attack helicopters by the UN mission in Cote d'Ivoire to oust Laurent Gbagbo from power in April 2011 and NATO's decision to interpret UN Security Council Resolution 1973 as permission for the use of airpower to assist the Transitional National Council of Libya to overthrow the Gaddafi regime provoked a strong response from several UN member states. Long-standing critics of the Responsibility to Protect (R2P), Nicaragua and Venezuela, used particularly blunt language to criticize what they saw as the UN's complicity in neoimperialist interventionism dressed up in humanitarian garb.

Nicaragua complained: "Once again we have witnessed the shameful manipulation of the slogan "protection of civilians" for dishonorable political purposes, seeking unequivocally and blatantly to impose regime change, attacking the sovereignty of a State Member of the United Nations [Libya] and violating the Organization's Charter. Once again, the logic of interventionism and hegemony has prevailed through a disastrous decision with incalculable potential consequences for tens of millions of individuals worldwide." Venezuela added "It is regrettable that certain countries are seeking regime change in Libya, in violation of the Charter of the United Nations. Those actions contravene resolution 1973 (2011), which calls for respect for the sovereignty and territorial integrity of Libya."(Bellamy \& Williams, 2011)

\section{Does the doctrine of "Responsibility to Protect" (R2P) apply in Syria?}

As revolutions sweeping over the Arab world reshape geopolitical arrangements and foreign policy, the international community is debating the rules of a possible humanitarian intervention in Syria. They have been watching, mostly on the sidelines, as the conflict devolves into a confused mess of guerrilla fighting that has ripped the small country at its seams. Reports of rampant human rights abuses, use of chemical weapons, and massacres of civilians have forced the world to ask: is international military intervention needed to protect the people of Syria? Although it is a prime case for intervention under R2P, the situation in Syria is quickly moving away from one that can be easily fixed by any sort of intervention. (Akshan \& Alwis, 2013).

Sparked by the embers of the Arab Spring in 2011, opposition forces are trying to oust President Bashar al-Assad's Baathist government and forces loyal to Assad are attempting to squash the rebellion in this theatre of war in the Middle East. The international community has been watching, mostly on the sidelines, as the conflict devolves into a confused mess of guerrilla fighting that has ripped the small country at its seams. Reports of rampant human rights abuses, use of chemical weapons, and massacres of civilians have forced the world to ask: is international military intervention needed to protect the people of Syria? (Akshan \& Alwis, 2013).

John Stuart Mill argued the following on intervention 
To go to war for an idea, if the war is aggressive, not defensive, is as criminal as to go to war for territory or revenue; for it is as little justifiable to force our ideas on other people, as to compel them to submit to our will in any other respect. But there assuredly are cases in which it is allowable to go to war, without having been ourselves attacked or threatened with attack; and it is very important that nations should make up their minds in time, as to what these cases are (Vardoulakis \& Kelly2010)

One of the most important, but often-overlooked aspects of R2P is "reasonable prospect". Will military action succeed in preventing loss of life, or will it exacerbate the situation and lead to greater loss of life? Although the NATO bombings of Yugoslavia successfully ended the war in Kosovo in 1999, most of the civilian casualties were due to collateral damage from bombing or retaliation to NATO bombings. An actual humanitarian intervention must be designed around preventing collateral damage and retaliatory killings. In the case of Syria, the murky nature of the guerrilla fighting and the growing sectarian ties of both the rebels and government forces make a potential military intervention extremely difficult. The urban nature of most of the fighting lends itself to collateral damage if either air-based-intervention or land-based-intervention is used. Although Syria is a prime case for intervention under R2P, the situation in Syria is quickly moving away from one that can be easily fixed by any sort of intervention.

\section{Conclusion}

In conclusion, the concept of Responsibility to Protect (R2P) based on the reviews of past studies is found to be morally justified and widely accepted by the international community, but difficult to implement. R2P concept is a challenge for public society and the broader peace movement. For Arab countries and some African countries where chaotic rain is falling every day, there is a need of R2P to overcome their problems. It is responsibility of R2P to ensure that genocides and wars against humanity do not occur and if they do how R2P can respond quickly and effectively to stop killings, torture and rapes. Therefore, a small group of dissenters continues to express concern that powerful countries will use R2P as pretense for military intervention.

\section{Corresponding Author}

Usman Safiyanu Duguri, Faculty of Law and International Relations, Universiti Sultan Zainal Abidin, Gong Badak Campus, 21300 Kuala Nerus, Terengganu, Malaysia.

Email: usmansufyanduguri@yahoo.com

\section{References}

Bellamy, A.J. (2008). The Responsibility to Protect and the problem of military intervention. International Affairs, 84(4), pp.615-639.

Bellamy, A.J. (2015). The Responsibility to Protect turns ten. Ethics \& International Affairs, 29(2), pp.161-185.

Bellamy, A.J. (2016). The Three Pillars of the Responsibility to Protect. Pensamiento Propio, (41). 
INTERNATIONAL JOURNAL OF ACADEMIC RESEARCH IN BUSINESS AND SOCIAL SCIENCES

Vol. 9, No. 3, March, 2019, E-ISSN: 222 2-6990 ¿ 2019 HRMARS

Brock, G. (2011). International Commission on Intervention and State Sovereignty (ICISS). In Encyclopedia of Global Justice(pp. 542-544). Springer Netherlands.

International Commission on Intervention, State Sovereignty and International Development Research Centre (Canada), (2001). The responsibility to protect: report of the International Commission on Intervention and State Sovereignty. Idrc.

Soderlund, W.C. (2013), June. The responsibility to prevent: From identification to implementation. In annual conference of the Canadian Political Science Association, June (pp. 4-6).

Stockburger, P. (2010). The Responsibility to Protect Doctrine: Customary International Law, an Emerging Legal Norm, or Just Wishful Thinking. Intercultural Hum. Rts. L. Rev., 5, p.365.

Welsh, J., Thielking, C. and MacFarlane, S.N. (2002). The responsibility to protect: assessing the report of the International Commission on Intervention and State Sovereignty. International Journal, 57(4), pp.489-512.

Zifcak, S. (2012). The responsibility to protect after Libya and Syria. Melb. J. Int'I L., 13, p.59.

Bellamy, A.J. and Williams, P.D. (2011). The new politics of protection? Côte d'Ivoire, Libya and the responsibility to protect. International Affairs, 87(4), pp.825-850.

International Commission on Intervention, State Sovereignty and International Development Research Centre (Canada), (2001). The responsibility to protect: report of the International Commission on Intervention and State Sovereignty. Idrc.

Focarelli, C. (2008). The responsibility to protect doctrine and humanitarian intervention: too many ambiguities for a working doctrine. Journal of conflict and security law, 13(2), pp.191-213.

Varouxakis, G. and Kelly, P. eds., (2010). John Stuart Mill: Thought and Influence: The Saint of Rationalism. Routledge.

Akshan, A. (2013). Does the doctrine of "responsibility to protect" (R2P) apply in Syria? 